\title{
Galectin-3: its role in asthma and potential as an anti-inflammatory target
}

Peng Gao ${ }^{1,2,3,4}$, Jodie L Simpson ${ }^{1,2}$, Jie Zhang ${ }^{3^{*}}$ and Peter G Gibson ${ }^{1,2^{*}}$

\begin{abstract}
Galectins constitute an evolutionary conserved family that bind to $\beta$-galactosides. Increasing evidence shows that galectins are involved in many fundamental biological processes such as cellular communication, inflammation, differentiation and apoptosis. Changes in galectin-3 (Gal-3) expression are commonly seen in cancer and pre-cancerous conditions, and Gal-3 may be involved in the regulation of diverse cancer cell activities that contribute to tumourigenesis, cancer progression and metastasis. In addition, Gal-3 is a pro-inflammatory regulator in rheumatoid arthritis. Gal-3 has been shown to be involved in many aspects in allergic inflammation, such as eosinophil recruitment, airway remodeling, development of a Th2 phenotype as well as increased expression of inflammatory mediators. In an in vivo model it was shown that bronchoalveolar lavage (BAL) fluid from ovalbumin-challenged mice contained significantly higher levels of Gal-3 compared to control mice. The molecular mechanisms of Gal-3 in human asthma have not been fully elucidated. This review will focus on what is known about the Gal-3 and its role in the pathophysiological mechanisms of asthma to evaluate the potential of Gal-3 as a biomarker and therapeutic target of asthma.
\end{abstract}

Keywords: Galectin-3, Inflammation, Leukocyte, Airway hyperresponsiveness, Airway remodeling

\section{Introduction}

Galectins are a family of evolutionary conserved animal lectins that bind to $\beta$-galactosides. They are ubiquitous in mammals and other vertebrate taxa, invertebrates, and fungi $[1,2]$. First described in the 1970s, galectins are involved in the recognition of carbohydrate ligands during embryogenesis [3]. In recent years, galectins have been shown to have significant immunoregulatory activities, such as cell differentiation, tissue organization, and the regulation of immune homeostasis [4,5]. Galectins have been shown to bind glycans on the surface of bacteria, viruses, protozoa and fungi, which indicates a potential role in the recognition of pathogens [6,7]. So far, 15 galectin members have been identified in a wide variety of tissues $[4,8]$. All galectins share close sequence homology in their carbohydrate recognition domain (CRD) but exhibit different affinities for different saccharide ligands [9]. Galectins can be bi- or multi-valent in terms of their ligand-binding

\footnotetext{
* Correspondence: doctorzhangj@sina.com; peter.gibson@hnehealth.nsw.gov.au ${ }^{3}$ Department of Respiratory Medicine, the Second Affiliated Hospital of Jilin University, Changchun, Jilin, China

'Department of Respiratory and Sleep Medicine, Hunter Medical Research Institute, Newcastle NSW2305, Australia

Full list of author information is available at the end of the article
}

activity (Figure 1), which accounts for their ability to cross-link cell surface glycoproteins. Based on structural differences, the galectins can be classified into three distinct subgroups [Figure 1]. Prototypic galectins (galectin$1,-2,-5,-7,-10,-11,-13,-14$, and -15) have one CRD and are capable of homodimerization. Tandem repeat type galectins (galectin-4, $-6,-8,-9$, and -12) consist of two distinct CRDs which are joined by a linker of up to 70 amino acids and have differential affinity for carbohydrates. Gal-3 is a unique member of chimera type galectins and exhibits both extracellular and intracellular functions. The protein contains a single CRD with an extended $\mathrm{N}$-terminus which plays a role in protein oligomerization and may participate in the interaction with other intracellular proteins [4,10-12]. This means that Gal-3 can interact with both carbohydrates and proteins.

Gal-3 was first discovered as an IgE-binding protein, and characterized as a $32 \mathrm{kDa}$ antigen (Mac-2) on the surface of murine macrophages [14]. Gal-3 is widely distributed and localizes to the extracellular space, cytoplasmic or nuclear regions. Like other members of the galectin family, Gal-3 does not possess a secretion signal peptide that would direct transport through the classical 


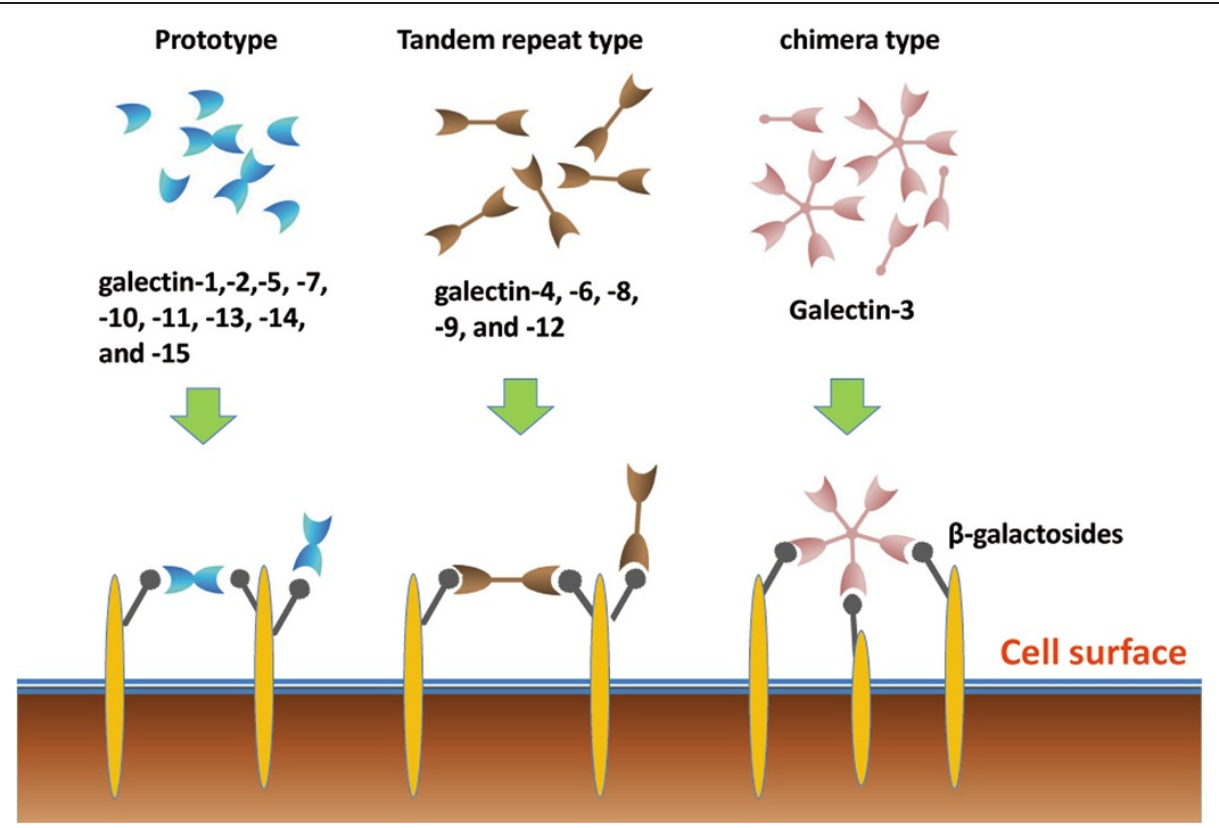

Figure 1 The structure and classification of different members of the galectin family. Adapted from [13].

endoplasmic reticulum-Golgi apparatus secretory pathway [10]. At low concentrations, Gal-3 is a monomer, or can potentially form oligomers but only upon binding to multivalent saccharides, a feature that imparts great flexibility on Gal-3. As a result of the activation of signaling pathways involved in the modulation of a number of cellular processes, Gal-3 can crosslink cell surface receptors, leading to the formation of lattices that cluster these ligands into lipid raft micro-domains [15-18]. These cellular processes include cell-cell adhesion, proliferation, differentiation, apoptosis, and cytokine secretion. Through protein-protein interactions, Gal-3 can react with many extracellular and/or intracellular proteins. This can be done in a carbohydrate dependent or independent manner respectively [19-23].

In recent decades, the literature on Gal-3 has been rapidly growing. The reason generating this increasing interest relates to the broad range of functions displayed by Gal-3. It has now been found that Gal-3 is related to the physiopathology of multiple diseases (Table 1). Gal-3 has been known to be involved in many aspects in asthma, such as eosinophil recruitment [24,25], airway remodeling, development of a Th2 phenotype as well as increased expression of inflammatory mediators [26]. This review will focus on what is known about the Gal-3 and its role in the pathophysiological mechanisms in asthma.

\section{Gal-3 in inflammation}

Asthma is a chronic inflammatory respiratory disease characterized by airway inflammation, airway hyperresponsiveness
(AHR) and reversible airway obstruction [34]. Treatments targeting eosinophilic inflammation in asthma are able to reduce asthma exacerbations, however the inflammatory mechanisms leading to asthma symptoms and AHR in the absence of sputum eosinophilia is poorly understood. Gal3 is potentially relevant in the pathogenesis of inflammation in asthma and its phenotypes.

\section{Gal-3 expression in the inflammatory setting}

A variety of tissues and cell types express Gal-3 under basal conditions, including epithelial cells, dendritic cells, macrophages and neutrophils $[11,35,36]$. However, the pattern of expression can be modulated in the inflammatory setting. In vivo, an increase in the extracellular concentration of Gal-3 has been measured in the inflammatory setting in animal models. Bronchoalveolar lavage (BAL) fluid from ovalbumin (OVA) challenged mice contained significantly higher levels of Gal-3 compared to control mice [24], similar to the results from mice infected with Streptococcus pneumonia [37]. Elevated levels of Gal-3 were also detected in prioninfected brain tissue [38], and in synovial tissue and serum from patients with rheumatoid arthritis (RA) [28]. In RA, serum Gal-3 levels were increased further in uncontrolled disease. In human asthma, highly variable Gal-3 expression was detected on both sputum macrophages and neutrophils by flow cytometry, and although it tended to be lower in asthmatic patients compared to healthy controls, this difference did not reach statistical significance [39]. 
Table 1 The levels of serum Gal-3 in different patients

\begin{tabular}{lll}
\hline Disease & Method and assay & Level in blood (ng/ml) \\
\hline Heart failure & ELISA (BG Medicine, & Decrease in left ventricular systolic \\
Waltham, USA). & function (LVEDV): 14.7(12.8-18.2); \\
& stable LVEDV: 17.9(13.7-22); \\
& increase in LVEDV: 19(14.9-24.4).
\end{tabular}

\author{
Comments \\ Patients were divided into three groups \\ according to the change in LVEDV: decrease \\ in LVEDV $>8 \%$, stable LVEDV (-8-8\%) and an \\ increase in LVEDV > 8\%. Plasma Gal-3 is associated \\ with left ventricular remodeling determined by \\ serial echocardiography and predicts long-term \\ mortality in patients with severe chronic heart \\ failure [27].
}

$\begin{array}{ll}\begin{array}{l}\text { Rheumatoid arthritis (RA) } \\ \text { ELISA (R\&D Systems, } \\ \text { Minneapolis, USA). }\end{array} & \begin{array}{l}\text { ELISA (R\&D Systems, } \\ \text { Juvenile idiopathic } \\ \text { arthritis (JIA) }\end{array} \\ \text { Behçet's disease (BD) } & \text { ELISA (R\&D Systems, } \\ & \text { Minneapolis, USA). } \\ \text { Cancer } & \text { In house ELISA }\end{array}$

ELISA (Bender MedSystems, Vienna, Austria).

ELISA (Human Gal-3

Assay Kit, IBL)

Gal-3 was elevated in RA serum and synovial fluids. In RA, serum Gal-3 correlated with C-reactive protein levels.

Healthy controls: 8.1(4.9-16.7); inactive disease: 18.6(9.7-28.8); active disease: $35.8(15.8-60.8)$.

Active BD patients: $13.08 \pm 1.53$; inactive BD patients: $8.08 \pm 0.71$; healthy controls: $7.59 \pm 0.48$.

Healthy control: 62(20-313); Breast cancer: 100(20-620); Gastrointestinal cancer: 185(20-950); Lung cancer: 171(20-807).

Controls: $3.07 \pm 0.69$; Colorectal cancer: $6.81 \pm 4.07$

Bladder cancer: 1.07(0.55-2.03) Control: 0.58(0.26-1.26)

Asthma serum: 1.5(1.1-1.9); healthy control: 1.8(0.8-2.1).
Gal-3 is not only involved in inflammation, but also contributes to the activation of synovial fibroblasts [28].

Serum levels of Gal-3 are highest in active JIA children, followed by inactive disease and controls [29].

Active BD patients had significantly higher levels of serum Gal-3 than inactive patients and controls [30].

Serum Gal-3 levels were significantly higher in subpopulations of patients having each type of tumor [31].

Gal-3 ranged higher in cancer patients than in controls [32].

Serum Gal-3 concentration of the bladder cancer patients was higher than that of controls [33].

Gal-3 in asthma serum was lower than that of controls (not published).

Data are expressed as mean \pm SD or median (IQR).

Similarly, both intracellular and surface expression of Gal-3 are enhanced after several different stimuli. Increased Gal-3 protein was detected in muscle endothelium by immunohistology accompanied by elevated Gal-3 in the serum of mice fed with a diet containing $60 \%$ fat calories [40]. Elevated levels of Gal-3 were also measured in both alveolar vascular endothelial cells and alveolar macrophages, indicating both cell types as a potential source of the elevated Gal-3 [41]. In human endothelium, Gal-3 is regulated at the protein level in response to IL-1 $\beta$, and at the mRNA level in response to advanced glycation end products casein (AGE-Cas) [42]. These findings are consistent with upregulation of Gal-3 with immune activation, since dietary fat and IL-1 $\beta$ are involved in innate immune activation. Furthermore, macrophages in the BAL of OVA challenged mice expressed large amounts of Gal-3, and these were the major cell type that contained Gal-3 [24]. In addition, the increased level of Gal-3 has also been detected on the surface of neutrophils [43], eosinophils [44], mast cell, monocytes and lymphocytes [25].

\section{Regulation of leukocyte trafficking and activation}

An increasing number of studies has demonstrated that Gal-3 plays a critical role in the process of leukocyte trafficking, activation and cytokine release. One facet of inflammation where Gal-3 appears to have beneficial effects is phagocytosis, which is necessary to clear pathogens, foreign bodies and cellular debris, thus allowing inflammation to resolve. Gal-3 can also regulate cell apoptosis from both inside and outside the cell (Figure 2) $[45,46]$. Moreover, Gal-3 is a unique member of the family with both anti- and pro-apoptotic activity [47]. Cytoplasmic Gal-3 binding to Fas would inhibit apoptosis by localising to the mitochondrial membrane to maintain mitochondrial membrane integrity and preventing the cytochrome c release [45,48-50]. In contrast, extracellular Gal-3 directly induces $\mathrm{T}$ cell death in a carbohydratedependent manner by binding to its cell surface receptors, such as CD7, CD29 [46].

\section{Macrophage/monocyte}

Gal-3, as a chemoattractant and adhesion factor, plays an important role in the trafficking of monocytes and macrophages. In vitro, recombinant human Gal-3 induces monocyte/macrophage migration. These processes could be inhibited by addition of lactose, specific mAb, and the C-terminal domain fragment. In addition, Gal-3 causes $\mathrm{Ca}^{2+}$ influx in monocytes, and both the chemotactic effect and the induction of $\mathrm{Ca}^{2+}$ influx involve a pertussis toxin-sensitive pathway, which suggests a role for G protein-coupled receptors [52]. In vivo, Gal-3- 


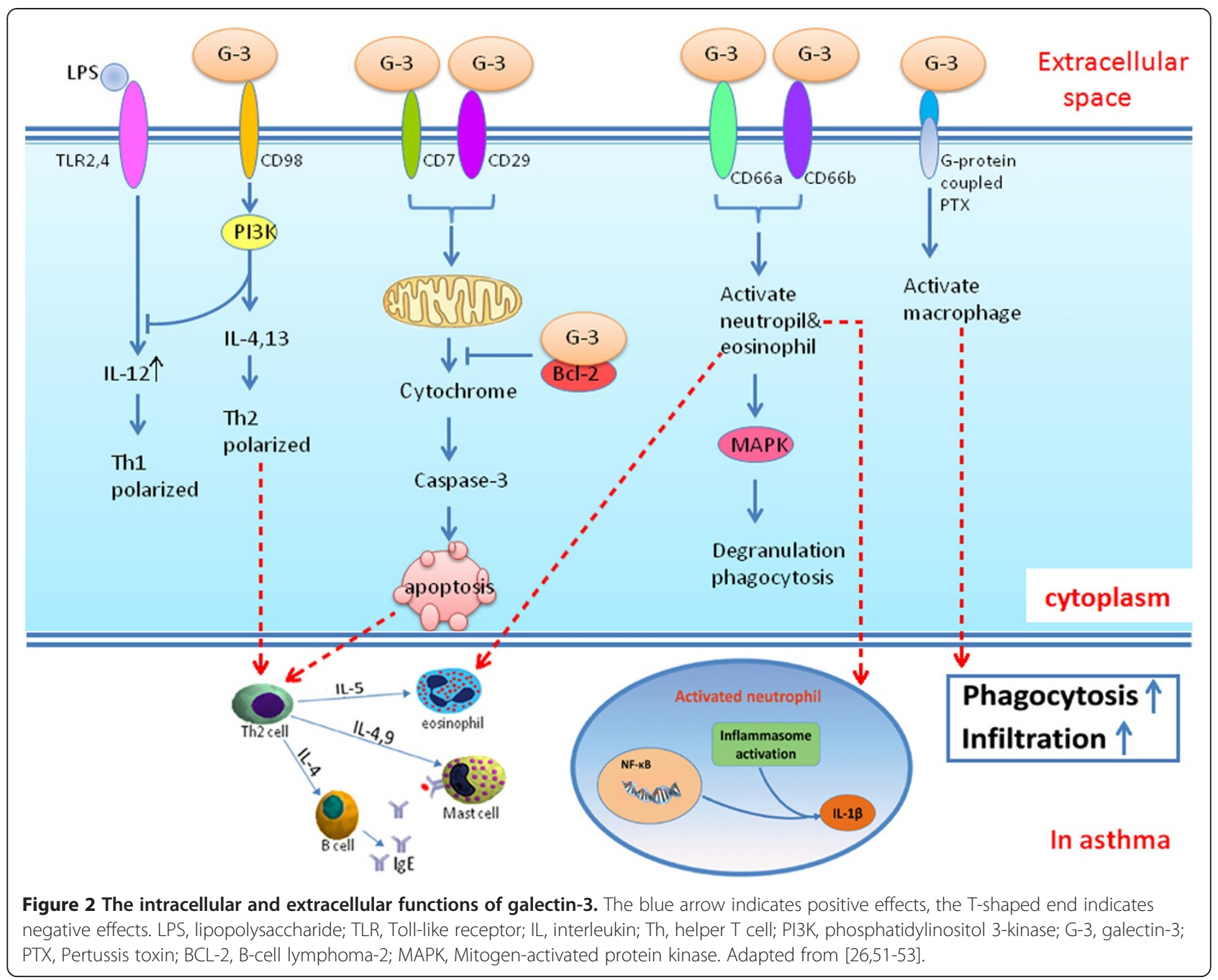

deficient mice develop significantly reduced numbers of peritoneal macrophages and granulocytes compared with wild-type mice when treated with thioglycolate i.p. [54,55].

Gal-3 can activate monocytes/macrophages through its lectin function (Figure 2). In vitro, Gal-3 (ie, approximately 10-100 nM) can induce optimal superoxide release from monocytes $[52,56]$ and promote the uptake of apoptotic neutrophils from monocyte derived macrophages [57]. Conversely, Gal-3 deficient macrophages exhibited reduced phagocytosis of IgG-opsonized erythrocytes and apoptotic thymocytes in vitro compared to wild type cells. In addition, Gal-3-/- mice showed attenuated phagocytic clearance of apoptotic thymocytes by peritoneal macrophages in vivo. These mice also exhibited reduced IgGmediated phagocytosis of erythrocytes by Kupffer cells in a murine model of autoimmune hemolytic anemia [58]. This is further corroborated by in vitro studies in which Gal-3 null macrophages demonstrate reduced phagocytosis of apoptotic neutrophils [37].
Alternative macrophage activation has been implicated in asthma [59-61]. Gal-3 has a property of negative regulation of LPS function, which protects the host from endotoxin shock while increasing Salmonella survival. In contrast, blocking Gal-3 binding sites enhanced LPSinduced inflammatory cytokine expression by wild-type macrophages [62]. Furthermore, Gal-3 deficient mice infected with Toxoplasma gondii, produced larger amounts of IL-12, and induced Th1 polarized immune response (Figure 2) [63]. The disruption of the Gal-3 gene specifically restrains $\mathrm{IL}-4 / 13$-induced alternative macrophage activation without affecting IFN- $\gamma /$ LPS-induced classical activation or IL-10-induced deactivation. This results were supported by other recent studies $[64,65]$.

\section{Neutrophil}

Gal-3 promotes the adhesion of human neutrophils $[66,67]$. Furthermore, in an in vivo streptococcal pneumonia mouse model, neutrophil extravasation was closely 
related to accumulation of Gal-3 in the alveolar space, which was $\beta_{2}$-integrin independent [67]. In peripheral blood neutrophils, cross-linking of CD66b, a candidate receptor for Gal-3, mediates the release of interleukin-8 from intracellular storage [68], the most potent chemoattractant for neutrophils. Some other results, in line with a decreased cellular infiltrate observed in numerous in vivo models of inflammation performed in Gal-3 knockout mice, have provided more evidence for a role for this protein in mediating leukocyte recruitment during an inflammatory response $[41,55,63,69]$. One of the possible explanations of the trafficking mechanisms is that the cross-linking of neutrophil CD66a and/or CD66b, the functional Gal-3 receptors, resulted in increased adhesion of the neutrophils to endothelial cells $[68,70]$. This hypothesis has been confirmed by the observation through confocal microscopy recently [71].

Concomitantly, Gal-3 can also activate neutrophils and enhance their phagocytic capabilities. Recombinant human Gal-3 could enhance human neutrophils to release superoxide through recognition of special cell surface glycoproteins. This activation is dose-dependent and the lectin property of Gal-3 is intrinsic to its carboxylterminal domain. Lactose could inhibit this process [72]. In addition, Gal-3 can also increase L-selectin shedding and interleukin-8 production in naïve and primed neutrophils. These activities required the presence of the Cterminal lectin domain and the $\mathrm{N}$-terminal nonlectin domain of Gal-3. On the other hand, after Gal-3 binds to primed neutrophils, the cells can cleave Gal-3, mainly through elastase, which damages the $\mathrm{N}$-terminal domain of Gal-3 [73].

In vivo Gal-3-/- mice develop more severe pneumonia after infection with $S$. pneumoniae, as demonstrated by increased bacteremia and lung damage compared to wild-type mice. Gal-3 reduces the severity of pneumococcal pneumonia in part by augmenting neutrophil phagocytosis of bacteria and delaying neutrophil apoptosis [37]. The mechanism of the increased phagocytosis of neutrophils by Gal-3 may be through the MAPK pathway and CD66 surface expression [Figure 2]. Disruption of this signaling pathway abrogated Gal-3 mediated modulation of neutrophil degranulation and phagocytosis $[70,74]$.

\section{Eosinophils}

In vitro, recombinant human Gal-3 can directly increase rolling and adhesion of eosinophils from allergic donors in an $\alpha-4$ integrin-dependent manner, with an effect comparable to that evoked by vascular cell adhesion molecule (VCAM)-1. These activities could be inhibited by specific Gal-3 mAbs as well as lactose [44]. Furthermore, CD66b, as an activation marker for human granulocytes, engaged by $\mathrm{mAb}$ or Gal-3, activated a Src kinase family molecule and resulted in cellular adhesion, superoxide production, and degranulation of eosinophils. Disruption of CD66b inhibited the adhesion and activation of eosinophils [53]. In vivo studies in Gal-3 knockout mice exhibited significantly lower eosinophil infiltration, serum IgE and IL-4 (Th2 cytokine) levels compared with wild type counterparts. This may indicate a direct effect for Gal-3 on eosinophil trafficking or suggest that Gal-3 is critical for the development of inflammatory Th2 responses. In its absence, mice develop a Th1-polarized response [25].

In contrast to these experiments, intratracheal instillation of plasmid DNA encoding Gal-3 in a OVA challenged-rat model led to normalization of the eosinophil and $\mathrm{T}$ cell count in BALF and that there was a strong concomitant inhibition of IL-5 mRNA in the lungs [75]. Twelve weeks after the first intranasal antigen instillation in chronically asthmatic mice, treatment with the Gal-3 gene led to an improvement in the eosinophil count and the normalization of hyperresponsiveness to methacholine. Concomitantly, this treatment resulted in an improvement in mucus secretion and subepithelial fibrosis in the chronically asthmatic mice, with a quantitatively measured reduction in lung collagen, a prominent feature of airway remodeling [76]. Similarly, treatment of chronic asthmatic mice with gene therapy using plasmid encoding Gal-3 led to inhibition of suppressor of cytokine signaling (SOCS) proteins 1 and 3, which led to an improvement in Th2 allergic inflammation [77]. Therefore, these results indicate that treatment with a plasmid encoding Gal-3 may not exactly reproduce the function of endogenous Gal-3, possibly because the protein may be expressed differently in the cells or tissues, in the intraversus extra-cellular modes of action, and in monomer or polymer between mice expressing a transgene and wildtype mice.

\section{Other cells}

Gal-3 also regulates the migratory pattern of dendritic cells (DCs). Gal-3 deficient DCs exhibited defective chemotaxis. Moreover, exogenous Gal-3 displays the activation of mast cells, such as mediator release [78,79], and the increased apoptosis of mast cells [80]. Gal-3 deficient mast cells showed a significantly lower amount of histamine, the cytokine IL-4, expression of IgE receptor and passive cutaneous anaphylaxis reactions [81].

In T cells, Gal-3 inhibits apoptosis by interacting with Bc1-2 in a lactose-inhibitable manner [45], and is necessary for IL-2 dependent cell growth [82]. Conversely, extracellular Gal-3 directly induces death of human thymocytes and $\mathrm{T}$ cells by binding to $\mathrm{T}$ cell surface glycoprotein receptors, such as $\mathrm{CD} 7, \mathrm{CD} 29, \mathrm{CD} 43, \mathrm{CD} 45$ and CD71 [83-88]. 


\section{Gal-3 in experimental models of asthma}

In a murine model of asthma treated with OVA, Gal$3+/+$ mice developed significantly enhanced allergic airway inflammation and AHR. Firstly, Gal-3 expression was significantly elevated in the airways of Gal-3+/+ mice, not only in the peribronchial inflammatory cells, but also in the fluid lining the airways as well. Secondly, Gal-3+/+ mice exhibit significantly elevated allergic airway inflammation, with an increased number of eosinophils compared with similarly treated Gal-3-/-. Thirdly, Gal-3-/- mice exhibited lower goblet cell metaplasia compared to Gal-3+/+ mice. Fourthly, Gal-3+/+ mice exhibited higher serum IgE levels than similarly treated Gal-3-/- mice. Fifthly, Gal-3 null mice display a lower Th2 response but a higher Th1 response. Finally, Gal-3+/+ mice manifest significantly higher airway responsiveness to methacholine compared to Gal-3-/- mice [24,89]. Furthermore, bone marrow derived mast cells (BMMC) from Gal-3 deficient mice not only secreted significantly lower levels of histamine and IL-4, but also exhibited lower expression of $\mathrm{IgE}$ receptor and reduced passive cutaneous anaphylaxis reactions compared with Gal-3+/+ BMMC. In addition, Gal-3-/- BMMC contained a significantly lower basal level of JNK1 protein than Gal-3+/+ BMMC, which is probably responsible for the lower IL-4 expression [81]. In a mouse model of chronic allergic airway inflammation exposed to OVA for 12 weeks, Gal-3-/- mice displayed significantly lower airway inflammatory responses than did wild-type mice, and lower amounts of airway remodeling [26].

\section{Gal-3 in human asthma}

The inflammatory response in asthma shows heterogeneity, which involves many cells and cellular elements [90]. Recognizing the different inflammatory phenotypes within asthma is important for understanding the underlying disease processes. The different inflammatory phenotypes are also clinically relevant due to potentially differing responses to therapeutic interventions. An important classification of asthma has been performed by Simpson JL, et al., in which asthmatic subjects were classified into four groups based on the presence of neutrophils and eosinophils using the 95th percentile from the healthy control subjects as a cut-off point [91]. This resulted in four inflammatory subtypes, including neutrophilic asthma, eosinophilic asthma, mixed granulocytic asthma and paucigranulocytic asthma. Recent years, many studies have demonstrated the distinct mechanisms of these subgroups, which are important because each subtype has a distinct mechanism and differential responses to therapy [92-98]. The mechanisms of eosinophilic asthma involve activation of Th2 pathways, typically by allergen, and release of Th2 cytokines, such as IL-4, 5, 9 and 13. Bronchial biopsies from these patients show infiltration with eosinophils, activated mast cells, and $\mathrm{T}$ cells that are predominantly $\mathrm{Th} 2$ cells [99].

However, the mechanisms of non-eosinophilic asthma are different from that of eosinophilic asthma. The neutrophilic form of asthma appears to be driven by infection and pollutant activation of innate immune responses, leading to active IL-1 $\beta$ secretion via TLR and NLRP3 inflammasome activation $[100,101]$.

It is likely that Gal-3 might be important in noneosinophilic forms of asthma. In murine models, exogenous Gal-3 has been linked to more severe AHR [24,26], but this effect is associated with down regulation of IL-5 gene expression after the treatment with plasmid encoding Gal-3 [75,76] and therefore the presence of noneosinophilic airways inflammation. While it is unknown if these kinds of experiments represent the function of endogenous Gal-3 these initially paradoxical effects (more AHR and less Th2 inflammation) can be explained in the context of an inflammatory phenotype, which displays the suppressed Th2 cytokines, and persistent AHR indicates a non-eosinophilic phenotype. Consistent with this, Gal-3 is present on sputum macrophages and neutrophils in asthma [39]. So far, studies of the level of Gal-3 in human asthma have not analyzed data by inflammatory phenotype. Available data only shows reduced Gal-3 gene expression in asthmatic sputum cells [39]. So, there is a need to elucidate how Gal-3 is involved in the mechanisms of asthma phenotypes.

\section{Conclusion}

As a multifunctional protein widely expressed by many types of inflammatory cells, Gal-3 overexpression and change of inter- and sub-cellular localization are commonly seen in various types of inflammatory cells. Growing evidence has shown that Gal-3, first discovered as an IgE-binding protein, is an important regulator of inflammatory cell infiltration, activation, and clearance. Recent studies of the murine models using Gal-3 gene transfer indicate that Gal-3 is anti-inflammatory, however these results might not represent the effect of endogenous Gal-3. In fact, a large number of in in vivo and in vitro studies suggest the Gal-3 is pro-inflammatory. This perplexing paradox may be explained by considering the heterogeneity of airway inflammation in asthma and the specific effects of Gal-3 as a mechanism of noneosinophilic forms of asthma. At present there are limited data available for levels and function of Gal-3 in human asthma or chronic obstructive pulmonary disease. Therefore, targeting the actions of Gal-3 might elucidate underlying molecular mechanisms of asthma and represent a promising therapeutic strategy for the development of effective therapeutic agents for asthma treatment. 


\section{Abbreviations}

AHR: Airway hyperresponsiveness; BALF: Bronchoalveolar lavage fluid; BCL-2: B-cell lymphoma-2; BMMC: Bone marrow derived mast cells; CRD: Carbohydrate recognition domain; Gal-3: Galectin-3; IL: Interleukin; LPS: Lipopolysaccharide; MAPK: Mitogen-activated protein kinase; OVA: Ovalbumin; PI3K: Phosphatidylinositol 3-kinase; PTX: Pertussis toxin; RA: Rheumatoid arthritis; SOCS: Suppressor of cytokine signaling; TLR: Toll-like receptor; Th: Helper T cell.

\section{Competing interests}

The authors declare that they have no competing interests.

\section{Authors' contributions}

PG drafted the manuscript. JS reviewed and revised it critically for important intellectual content. JZ and PGG have made substantial contributions to conception and design, and have given final approval of the version to be published. All authors read and approved the final manuscript.

\section{Authors' information}

J Zhang and PG Gibson are joint corresponding authors to this manuscript.

\section{Author details}

${ }^{1}$ Department of Respiratory and Sleep Medicine, Hunter Medical Research Institute, Newcastle NSW2305, Australia. ${ }^{2}$ Priority Research Centre for Asthma and Respiratory Diseases and Hunter Medical Research Institute, The University of Newcastle, Callaghan NSW 2308, Australia. ${ }^{3}$ Department of Respiratory Medicine, the Second Affiliated Hospital of Jilin University, Changchun, Jilin, China. ${ }^{4}$ Changchun Central Hospital, Changchun, Jilin, China.

Received: 21 June 2013 Accepted: 4 December 2013

Published: 9 December 2013

\section{References}

1. Cooper DN: Galectinomics: finding themes in complexity. Biochim Biophys Acta 2002, 1572:209-231

2. Vasta GR, Quesenberry M, Ahmed H, O'Leary N: C-type lectins and galectins mediate innate and adaptive immune functions: their roles in the complement activation pathway. Dev Comp Immunol 1999, 23:401-420

3. Vasta GR: Galectins as pattern recognition receptors: structure, function and evolution. Adv Exp Med Biol 2012, 946:21-36.

4. Leffler H, Carlsson S, Hedlund M, Qian Y, Poirier F: Introduction to galectins. Glycoconj J 2004, 19:433-440.

5. Yang RY, Rabinovich GA, Liu FT: Galectins: structure, function and therapeutic potential. Expert Rev Mol Med 2008, 10:e17.

6. Sato S, Nieminen J: Seeing strangers or announcing "danger": galectin-3 in two models of innate immunity. Glycoconj J 2004, 19:583-591.

7. Vasta GR: Roles of galectins in infection. Nat Rev Microbiol 2009, 7:424-438.

8. Rabinovich GA: Galectins: an evolutionarily conserved family of animal lectins with multifunctional properties; a trip from the gene to clinical therapy. Cell Death Differ 1999, 6:711-721.

9. Di Lella S, Sundblad V, Cerliani JP, Guardia CM, Estrin DA, Vasta GR, Rabinovich GA: When galectins recognize glycans: from biochemistry to physiology and back again. Biochemistry 2011, 50:7842-7857.

10. Cooper DN, Barondes SH: God must love galectins; he made so many of them. Glycobiology 1999, 9:979-984.

11. Liu FT: Galectins: a new family of regulators of inflammation. Clin Immunol 2000, 97:79-88.

12. Cummings RD, Liu FT: Galectins. In Essentials of Glycobiology. Edited by Varki A Cummings RD, Esko JD, Freeze HH, Stanley P, Bertozzi CR, Hart GW, Etzler ME. La Jolla, California: Cold Spring Harbor NY: The Consortium of Glycobiology Editors; 2009

13. Rabinovich GA, Toscano MA: Turning 'sweet' on immunity: galectin-glycan interactions in immune tolerance and inflammation. Nat Rev Immunol 2009, 9:338-352

14. Ho MK, Springer TA: Mac-2, a novel 32,000 Mr mouse macrophage subpopulation-specific antigen defined by monoclonal antibodies. J Immunol 1982, 128:1221-1228.

15. Rabinovich GA, Toscano MA, Jackson SS, Vasta GR: Functions of cell surface galectin-glycoprotein lattices. Curr Opin Struct Biol 2007, 17:513-520.
16. Brewer CF, Miceli MC, Baum LG: Clusters, bundles, arrays and lattices: novel mechanisms for lectin-saccharide-mediated cellular interactions. Curr Opin Struct Biol 2002, 12:616-623

17. Partridge EA, Le Roy C, Di Guglielmo GM, Pawling J, Cheung P, Granovsky M, Nabi IR, Wrana JL, Dennis JW: Regulation of cytokine receptors by Golgi N-glycan processing and endocytosis. Science 2004, 306:120-124.

18. Liu FT, Rabinovich GA: Galectins as modulators of tumour progression. Nat Rev Cancer 2005, 5:29-41.

19. Elad-Sfadia G, Haklai R, Balan E, Kloog Y: Galectin-3 augments K-Ras activation and triggers a Ras signal that attenuates ERK but not phosphoinositide 3-kinase activity. J Biol Chem 2004, 279:34922-34930.

20. Menon RP, Strom M, Hughes RC: Interaction of a novel cysteine and histidine-rich cytoplasmic protein with galectin-3 in a carbohydrateindependent manner. FEBS Lett 2000, 470:227-231.

21. Paron I, Scaloni A, Pines A, Bachi A, Liu FT, Puppin C, Pandolfi M, Ledda L, Di Loreto C, Damante G, Tell G: Nuclear localization of Galectin-3 in transformed thyroid cells: a role in transcriptional regulation. Biochem Biophys Res Commun 2003, 302:545-553.

22. Shimura T, Takenaka Y, Fukumori T, Tsutsumi S, Okada K, Hogan V, Kikuchi A, Kuwano H, Raz A: Implication of galectin-3 in Wnt signaling. Cancer Res 2005, 65:3535-3537.

23. Shimura T, Takenaka Y, Tsutsumi S, Hogan V, Kikuchi A, Raz A: Galectin-3, a novel binding partner of beta-catenin. Cancer Res 2004, 64:6363-6367.

24. Zuberi RI, Hsu DK, Kalayci O, Chen HY, Sheldon HK, Yu L, Apgar JR, Kawakami T, Lilly CM, Liu FT: Critical role for galectin-3 in airway inflammation and bronchial hyperresponsiveness in a murine model of asthma. Am J Pathol 2004, 165:2045-2053.

25. Saegusa J, Hsu DK, Chen HY, Yu L, Fermin A, Fung MA, Liu FT: Galectin-3 is critical for the development of the allergic inflammatory response in a mouse model of atopic dermatitis. Am J Pathol 2009, 174:922-931.

26. Ge XN, Bahaie NS, Kang BN, Hosseinkhani MR, Ha SG, Frenzel EM, Liu FT, Rao SP, Sriramarao P: Allergen-induced airway remodeling is impaired in galectin-3-deficient mice. J Immunol 2010, 185:1205-1214.

27. Lok DJ, Lok SI, de la Porte Bruggink-Andre PW, Badings E, Lipsic E, van Wijngaarden J, de Boer RA, van Veldhuisen DJ, van der Meer P: Galectin-3 is an independent marker for ventricular remodeling and mortality in patients with chronic heart failure. Clin Res Cardiol 2013, 102:103-110.

28. Ohshima S, Kuchen S, Seemayer CA, Kyburz D, Hirt A, Klinzing S, Michel BA Gay RE, Liu FT, Gay S, Neidhart M: Galectin 3 and its binding protein in rheumatoid arthritis. Arthritis Rheum 2003, 48:2788-2795.

29. Ezzat MH, El-Gammasy TM, Shaheen KY, Osman AO: Elevated production of galectin-3 is correlated with juvenile idiopathic arthritis disease activity, severity, and progression. Int J Rheum Dis 2011, 14:345-352.

30. Lee YJ, Kang SW, Song JK, Park JJ, Bae YD, Lee EY, Lee EB, Song YW: Serum galectin-3 and galectin-3 binding protein levels in Behcet's disease and their association with disease activity. Clin Exp Rheumatol 2007, 25:\$41-\$45.

31. Iurisci I, Tinari N, Natoli C, Angelucci D, Cianchetti E, lacobelli S: Concentrations of galectin-3 in the sera of normal controls and cancer patients. Clin Cancer Res 2000, 6:1389-1393.

32. Iacovazzi PA, Notarnicola M, Caruso MG, Guerra V, Frisullo S, Altomare DF: Serum levels of galectin-3 and its ligand $90 \mathrm{k} / \mathrm{mac}-2 \mathrm{bp}$ in colorectal cancer patients. Immunopharmacol Immunotoxicol 2010, 32:160-164.

33. Sakaki M, Oka N, Nakanishi R, Yamaguchi K, Fukumori T, Kanayama HO: Serum level of galectin-3 in human bladder cancer. J Med Invest 2008, 55:127-132.

34. Busse WW, Lemanske RF Jr: Asthma. N Engl J Med 2001, 344:350-362.

35. Gritzmacher CA, Robertson MW, Liu FT: IgE-binding protein. Subcellular location and gene expression in many murine tissues and cells. J Immunol 1988, 141:2801-2806.

36. Liu FT, Patterson RJ, Wang JL: Intracellular functions of galectins. Biochim Biophys Acta 2002, 1572:263-273.

37. Farnworth SL, Henderson NC, Mackinnon AC, Atkinson KM, Wilkinson T, Dhaliwal K, Hayashi K, Simpson AJ, Rossi AG, Haslett C, Sethi T: Galectin-3 reduces the severity of pneumococcal pneumonia by augmenting neutrophil function. Am J Pathol 2008, 172:395-405.

38. Mok SW, Riemer C, Madela K, Hsu DK, Liu FT, Gultner S, Heise I, Baier M: Role of galectin-3 in prion infections of the CNS. Biochem Biophys Res Commun 2007, 359:672-678.

39. Sanchez-Cuellar S, De la Fuente H, Cruz-Adalia A, Lamana A, Cibrian D, Giron RM, Vara A, Sanchez-Madrid F, Ancochea J: Reduced expression of galectin-1 and 
galectin-9 by leucocytes in asthma patients. Clin Exp Immunol 2012, 170:365-374.

40. Darrow AL, Shohet RV, Maresh JG: Transcriptional analysis of the endothelial response to diabetes reveals a role for galectin-3. Physiol Genomics 2011, 43:1144-1152.

41. Nieminen J, St-Pierre C, Bhaumik P, Poirier F, Sato S: Role of galectin-3 in leukocyte recruitment in a murine model of lung infection by Streptococcus pneumoniae. J Immunol 2008, 180:2466-2473.

42. Deo P, Glenn JV, Powell LA, Stitt AW, Ames JM: Upregulation of oxidative stress markers in human microvascular endothelial cells by complexes of serum albumin and digestion products of glycated casein. J Biochem Mol Toxicol 2009, 23:364-372

43. Gil CD, La M, Perretti M, Oliani SM: Interaction of human neutrophils with endothelial cells regulates the expression of endogenous proteins annexin 1, galectin-1 and galectin-3. Cell Biol Int 2006, 30:338-344.

44. Rao SP, Wang Z, Zuberi RI, Sikora L, Bahaie NS, Zuraw BL, Liu FT, Sriramarao P: Galectin-3 functions as an adhesion molecule to support eosinophil rolling and adhesion under conditions of flow. J Immunol 2007, 179:7800-7807.

45. Yang RY, Hsu DK, Liu FT: Expression of galectin-3 modulates T-cell growth and apoptosis. Proc Natl Acad Sci U S A 1996, 93:6737-6742.

46. Fukumori T, Takenaka Y, Yoshii T, Kim HR, Hogan V, Inohara H, Kagawa S, Raz A: CD29 and CD7 mediate galectin-3-induced type II T-cell apoptosis. Cancer Res 2003, 63:8302-8311.

47. Rabinovich GA, Baum LG, Tinari N, Paganelli R, Natoli C, Liu FT, lacobelli S: Galectins and their ligands: amplifiers, silencers or tuners of the inflammatory response? Trends Immunol 2002, 23:313-320.

48. Moon BK, Lee YJ, Battle P, Jessup JM, Raz A, Kim HR: Galectin-3 protects human breast carcinoma cells against nitric oxide-induced apoptosis: implication of galectin-3 function during metastasis. Am J Pathol 2001, 159:1055-1060.

49. Yu F, Finley RL Jr, Raz A, Kim HR: Galectin-3 translocates to the perinuclear membranes and inhibits cytochrome $c$ release from the mitochondria. A role for synexin in galectin-3 translocation. J Biol Chem 2002, 277:15819-15827.

50. Matarrese $\mathrm{P}$, Tinari N, Semeraro ML, Natoli C, lacobelli S, Malorni W: Galectin-3 overexpression protects from cell damage and death by influencing mitochondrial homeostasis. FEBS Lett 2000, 473:311-315.

51. Dumic J, Dabelic S, Flogel M: Galectin-3: an open-ended story. Biochim Biophys Acta 2006, 1760:616-635.

52. Sano H, Hsu DK, Yu L, Apgar JR, Kuwabara I, Yamanaka T, Hirashima M, Liu FT: Human galectin-3 is a novel chemoattractant for monocytes and macrophages. J Immunol 2000, 165:2156-2164.

53. Yoon J, Terada A, Kita H: CD66b regulates adhesion and activation of human eosinophils. J Immunol 2007, 179:8454-8462.

54. Hsu DK, Yang RY, Pan Z, Yu L, Salomon DR, Fung-Leung WP, Liu FT Targeted disruption of the galectin- 3 gene results in attenuated peritoneal inflammatory responses. Am J Pathol 2000, 156:1073-1083.

55. Colnot C, Ripoche MA, Milon G, Montagutelli X, Crocker PR, Poirier F: Maintenance of granulocyte numbers during acute peritonitis is defective in galectin-3-null mutant mice. Immunology 1998, 94:290-296.

56. Liu FT, Hsu DK, Zuberi Rl, Kuwabara I, Chi EY, Henderson WR Jr: Expression and function of galectin-3, a beta-galactoside-binding lectin, in human monocytes and macrophages. Am J Pathol 1995, 147:1016-1028.

57. Karlsson A, Christenson K, Matlak M, Bjorstad A, Brown KL, Telemo E, Salomonsson E, Leffler H, Bylund J: Galectin-3 functions as an opsonin and enhances the macrophage clearance of apoptotic neutrophils. Glycobiology 2009, 19:16-20.

58. Sano H, Hsu DK, Apgar JR, Yu L, Sharma BB, Kuwabara I, Izui S, Liu FT: Critical role of galectin-3 in phagocytosis by macrophages. J Clin Invest 2003, 112:389-397.

59. Nair MG, Cochrane DW, Allen JE: Macrophages in chronic type 2 inflammation have a novel phenotype characterized by the abundant expression of $Y \mathrm{~m} 1$ and Fizz1 that can be partly replicated in vitro. Immunol Lett 2003, 85:173-180.

60. Raes G, Brys L, Dahal BK, Brandt J, Grooten J, Brombacher F, Vanham G, Noel W, Bogaert P, Boonefaes T, et al: Macrophage galactose-type C-type lectins as novel markers for alternatively activated macrophages elicited by parasitic infections and allergic airway inflammation. J Leukoc Biol 2005, 77:321-327.
61. Wynn TA: Fibrotic disease and the $T(H) 1 / T(H) 2$ paradigm. Nat Rev Immunol 2004, 4:583-594.

62. Li Y, Komai-Koma M, Gilchrist DS, Hsu DK, Liu FT, Springall T, Xu D: Galectin-3 is a negative regulator of lipopolysaccharide-mediated inflammation. $\mathrm{J}$ Immunol 2008, 181:2781-2789.

63. Bernardes ES, Silva NM, Ruas LP, Mineo JR, Loyola AM, Hsu DK, Liu FT, Chammas R, Roque-Barreira MC: Toxoplasma gondii infection reveals a novel regulatory role for galectin-3 in the interface of innate and adaptive immunity. Am J Pathol 2006, 168:1910-1920.

64. MacKinnon AC, Farnworth SL, Hodkinson PS, Henderson NC, Atkinson KM, Leffler H, Nilsson UJ, Haslett C, Forbes SJ, Sethi T: Regulation of alternative macrophage activation by galectin-3. J Immunol 2008, $180: 2650-2658$

65. Cumpstey I, Sundin A, Leffler H, Nilsson UJ: C2-symmetrical thiodigalactoside bis-benzamido derivatives as high-affinity inhibitors of galectin-3: efficient lectin inhibition through double arginine-arene interactions. Angew Chem Int Ed Engl 2005, 44:5110-5112.

66. Kuwabara I, Liu FT: Galectin-3 promotes adhesion of human neutrophils to laminin. J Immunol 1996, 156:3939-3944.

67. Sato S, Ouellet N, Pelletier I, Simard M, Rancourt A, Bergeron MG: Role of galectin-3 as an adhesion molecule for neutrophil extravasation during streptococcal pneumonia. J Immunol 2002, 168:1813-1822.

68. Schroder AK, Uciechowski P, Fleischer D, Rink L: Crosslinking of CD66B on peripheral blood neutrophils mediates the release of interleukin-8 from intracellular storage. Hum Immunol 2006, 67:676-682.

69. Colnot C, Fowlis D, Ripoche MA, Bouchaert I, Poirier F: Embryonic implantation in galectin 1/galectin 3 double mutant mice. Dev Dyn 1998, 211:306-313.

70. Feuk-Lagerstedt $\mathrm{E}$, Jordan ET, Leffler $\mathrm{H}$, Dahlgren C, Karlsson A: Identification of CD66a and CD66b as the major galectin-3 receptor candidates in human neutrophils. J Immunol 1999, 163:5592-5598.

71. Nieminen J, Kuno A, Hirabayashi J, Sato S: Visualization of galectin-3 oligomerization on the surface of neutrophils and endothelial cells using fluorescence resonance energy transfer. J Biol Chem 2007, 282:1374-1383.

72. Yamaoka A, Kuwabara I, Frigeri LG, Liu FT: A human lectin, galectin-3 (epsilon bp/Mac-2), stimulates superoxide production by neutrophils. J Immunol 1995, 154:3479-3487.

73. Nieminen J, St-Pierre C, Sato S: Galectin-3 interacts with naive and primed neutrophils, inducing innate immune responses. J Leukoc Biol 2005, 78:1127-1135.

74. Fernandez GC, Ilarregui JM, Rubel CJ, Toscano MA, Gomez SA, Beigier Bompadre M, Isturiz MA, Rabinovich GA, Palermo MS: Galectin-3 and soluble fibrinogen act in concert to modulate neutrophil activation and survival: involvement of alternative MAPK pathways. Glycobiology 2005, 15:519-527.

75. Del Pozo V, Rojo M, Rubio ML, Cortegano I, Cardaba B, Gallardo S, Ortega M, Civantos E, Lopez E, Martin-Mosquero C, et al: Gene therapy with galectin-3 inhibits bronchial obstruction and inflammation in antigen-challenged rats through interleukin-5 gene downregulation. Am J Respir Crit Care Med 2002, 166:732-737.

76. Lopez E, Del Pozo V, Miguel T, Sastre B, Seoane C, Civantos E, Llanes E, Baeza ML, Palomino P, Cardaba B, et al: Inhibition of chronic airway inflammation and remodeling by galectin-3 gene therapy in a murine model. J Immunol 2006, 176:1943-1950.

77. Lopez E, Zafra MP, Sastre B, Gamez C, Lahoz C, Del Pozo V: Gene expression profiling in lungs of chronic asthmatic mice treated with galectin-3: downregulation of inflammatory and regulatory genes. Mediators Inflamm 2011, 2011:823279.

78. Frigeri LG, Zuberi RI, Liu FT: Epsilon BP, a beta-galactoside-binding animal lectin, recognizes IgE receptor (Fc epsilon $\mathrm{RI}$ ) and activates mast cells. Biochemistry 1993, 32:7644-7649.

79. Zuberi Rl, Frigeri LG, Liu FT: Activation of rat basophilic leukemia cells by epsilon BP, an lgE-binding endogenous lectin. Cell Immunol 1994, 156:1-12.

80. Suzuki Y, Inoue T, Yoshimaru T, Ra C: Galectin-3 but not galectin-1 induces mast cell death by oxidative stress and mitochondrial permeability transition. Biochim Biophys Acta 2008, 1783:924-934.

81. Chen HY, Sharma BB, Yu L, Zuberi R, Weng IC, Kawakami Y, Kawakami T, Hsu DK, Liu FT: Role of galectin-3 in mast cell functions: galectin-3-deficient mast cells exhibit impaired mediator release and defective JNK expression. J Immunol 2006, 177:4991-4997. 
82. Joo HG, Goedegebuure PS, Sadanaga N, Nagoshi M, Von Bernstorff W, Eberlein TJ: Expression and function of galectin-3, a beta-galactosidebinding protein in activated T lymphocytes. J Leukoc Biol 2001, 69:555-564.

83. Stillman BN, Hsu DK, Pang M, Brewer CF, Johnson P, Liu FT, Baum LG: Galectin-3 and galectin-1 bind distinct cell surface glycoprotein receptors to induce T cell death. J Immunol 2006, 176:778-789.

84. Arencibia I, Frankel G, Sundqvist KG: Induction of cell death in T lymphocytes by invasin via beta1-integrin. Eur J Immunol 2002, 32:1129-1138.

85. Brown TJ, Shuford WW, Wang WC, Nadler SG, Bailey TS, Marquardt H, Mittler RS: Characterization of a CD43/leukosialin-mediated pathway for inducing apoptosis in human T-lymphoblastoid cells. J Biol Chem 1996, 271:27686-27695.

86. Lesage S, Steff AM, Philippoussis F, Page M, Trop S, Mateo V, Hugo P: CD4+ CD8+ thymocytes are preferentially induced to die following CD45 cross-linking, through a novel apoptotic pathway. J Immunol 1997, 159:4762-4771.

87. Moura IC, Lepelletier Y, Arnulf B, England P, Baude C, Beaumont C, Bazarbachi A, Benhamou M, Monteiro RC, Hermine O: A neutralizing monoclonal antibody ( $m A b \mathrm{~A} 24$ ) directed against the transferrin receptor induces apoptosis of tumor T lymphocytes from ATL patients. Blood 2004, 103:1838-1845.

88. Ng PP, Dela Cruz JS, Sorour DN, Stinebaugh JM, Shin SU, Shin DS, Morrison SL, Penichet ML: An anti-transferrin receptor-avidin fusion protein exhibits both strong proapoptotic activity and the ability to deliver various molecules into cancer cells. Proc Natl Acad Sci U S A 2002, 99:10706-10711.

89. Wills-Karp M: Immunologic basis of antigen-induced airway hyperresponsiveness. Annu Rev Immunol 1999, 17:255-281.

90. Bateman ED, Hurd SS, Barnes PJ, Bousquet J, Drazen JM, FitzGerald M, Gibson P, Ohta K, O'Byrne P, Pedersen SE, et al: Global strategy for asthma management and prevention: GINA executive summary. Eur Respir J 2008, 31:143-178.

91. Simpson JL, Scott R, Boyle MJ, Gibson PG: Inflammatory subtypes in asthma: assessment and identification using induced sputum. Respirology 2006, 11:54-61.

92. Kips JC, O'Connor BJ, Langley SJ, Woodcock A, Kerstjens HA, Postma DS, Danzig M, Cuss F, Pauwels RA: Effect of SCH55700, a humanized anti-human interleukin-5 antibody, in severe persistent asthma: a pilot study. Am J Respir Crit Care Med 2003, 167:1655-1659.

93. Leckie MJ, Ten Brinke A, Khan J, Diamant Z, O'Connor BJ, Walls CM, Mathur AK, Cowley HC, Chung KF, Djukanovic R, et al: Effects of an interleukin-5 blocking monoclonal antibody on eosinophils, airway hyperresponsiveness, and the late asthmatic response. Lancet 2000 356:2144-2148.

94. Flood-Page P, Swenson C, Faiferman I, Matthews J, Williams M, Brannick L, Robinson D, Wenzel S, Busse W, Hansel TT, Barnes NC: A study to evaluate safety and efficacy of mepolizumab in patients with moderate persistent asthma. Am J Respir Crit Care Med 2007, 176:1062-1071.

95. Haldar P, Brightling CE, Hargadon B, Gupta S, Monteiro W, Sousa A, Marshall RP, Bradding P, Green RH, Wardlaw AJ, Pavord ID: Mepolizumab and exacerbations of refractory eosinophilic asthma. N Engl J Med 2009, 360:973-984.

96. Nair P, Pizzichini MM, Kjarsgaard M, Inman MD, Efthimiadis A, Pizzichini E, Hargreave FE, O'Byrne PM: Mepolizumab for prednisone-dependent asthma with sputum eosinophilia. N Engl J Med 2009, 360:985-993.

97. Corren J, Busse W, Meltzer EO, Mansfield L, Bensch G, Fahrenholz J, Wenzel SE, Chon Y, Dunn M, Weng HH, Lin SL: A randomized, controlled, phase 2 study of AMG 317, an IL-4Ralpha antagonist, in patients with asthma. Am J Respir Crit Care Med 2010, 181:788-796.

98. Barnes PJ: Immunology of asthma and chronic obstructive pulmonary disease. Nat Rev Immunol 2008, 8:183-192.
99. Woodruff PG, Modrek B, Choy DF, Jia G, Abbas AR, Ellwanger A, Koth LL, Arron JR, Fahy JV: T-helper type 2-driven inflammation defines major subphenotypes of asthma. Am J Respir Crit Care Med 2009, 180:388-395

100. Dos Santos G, Kutuzov MA, Ridge KM: The inflammasome in lung diseases. Am J Physiol Lung Cell Mol Physiol 2012, 303:L627-L633.

101. Mortaz E, Masjedi MR, Allameh A, Adcock IM: Inflammasome signaling in pathogenesis of lung diseases. Curr Pharm Des 2012, 18:2320-2328.

doi:10.1186/1465-9921-14-136

Cite this article as: Gao et al:: Galectin-3: its role in asthma and potential as an anti-inflammatory target. Respiratory Research 2013 14:136.

\section{Submit your next manuscript to BioMed Central and take full advantage of:}

- Convenient online submission

- Thorough peer review

- No space constraints or color figure charges

- Immediate publication on acceptance

- Inclusion in PubMed, CAS, Scopus and Google Scholar

- Research which is freely available for redistribution

Submit your manuscript at www.biomedcentral.com/submit
C) Biomed Central 